\title{
The calcitonin-CGRP gene in the infantile hypercalcaemia/Williams-Beuren syndrome
}

\author{
G A HitMAN*, L GARDE*, W DAOUD†, G J A I SNODGRASS + , \\ AND R D COHEN* \\ From the Medical Unit* and Department of Paediatricst, The London Hospital Medical College, \\ London E1 $1 B B$.
}

SUMmARY We have investigated 13 families, each of which have one member with infantile hypercalcaemia/Williams-Beuren syndrome (IHWBS), for either a germ cell mutation of, or an association with, the calcitonin-CGRP gene. Restriction fragment mapping studies of the calcitonin-CGRP gene using five restriction enzymes (TaqI, BglII, PvuII, PstI, and SacI) and region specific probes failed to show any abnormalities of this gene complex. No association of IHWBS with polymorphism of the calcitonin-CGRP/parathormone locus was found. Therefore, although the aetiology of IHWBS may be caused by a new dominant mutation, there is no evidence to implicate major rearrangements of the calcitonin-CGRP and parathormone genes.

The infantile hypercalcaemia/Williams-Beuren syndrome (IHWBS) is a congenital disorder characterised by mental retardation, stenoses of the aorta (especially supravalvular aortic stenosis) and other large vessels, a distinctive facial appearance, and transient but often severe hypercalcaemia in infancy. ${ }^{1-6}$ On reviewing 117 patients with this disorder $29 \%$ were found to be hypertensive; although a proportion of these could be explained by renal artery stenoses there is no evidence that this is the only mechanism involved. ${ }^{4}$

The disorder occurs in approximately one in every 20000 live births and its incidence has remained constant in the UK at about 18 per year for the last 20 years. ${ }^{4}$ In British families this disease appears to be sporadic with no other members of the family being affected; the one exception is a pair of identical twins (family 5, fig 1 ) who are concordant for the disease. ${ }^{4}$ Occasional familial cases have been published: one additional pair of monozygotic twins ${ }^{7}$ and a pair of second cousins, ${ }^{8}$ and Cortada et al ${ }^{9}$ described the syndrome in a mother and her dizygotic twin daughters. In this family of Cortada et al the diagnosis has been challenged by Burn, who thought it more resembled Noonan's syndrome. ${ }^{6}$

Supravalvular aortic stenosis (SVAS) occurs both sporadically and within families. The sporadic form can be subdivided into cases of IHWBS or SVAS alone (with normal facies and intelligence). Familial

Received for publication 30 March 1989

Accepted for publication 25 April 1989. cases follow an autosomal dominant mode of inheritance and usually have normal facial appearance and normal intelligence. Interestingly, the combination of SVAS, pulmonary stenosis, and hypercalcaemia has been reported in a 28 week human fetus investigated for severe non-immune hydrops; the parents were both first cousins suggesting (if this was IHWBS) an autosomal recessive mode of inheritance. ${ }^{10}$ These observations give rise to a number of hypotheses to explain the sporadic and possible familial cases. The first is that a germ cell mutation has occurred in one of the gametes or in the fertilised ovum. This might explain the wide range of abnormalities seen in this condition together with its sporadic nature and would be consistent with the identical twins being concordant for the disease. Alternatively, although less likely, infantile hypercalcaemia segregates as a rare autosomal recessive disease which is almost invariably lethal in utero; however, exceptionally, there is a live birth (in less than $1 \%$ cases). The latter hypothesis would then explain the apparent 'sporadic' nature of the disease with a few familial cases being described. Against this hypothesis there is no evidence of an increased miscarriage rate in women who have had offspring with IHWBS, although it should be borne in mind that early fetal losses would not be detected.

We have investigated these hypotheses in 13 families with IHWBS by studying the calcitoninCGRP gene complex on the short arm of chromosome $11 .^{11} 12$ This complex was chosen for several 

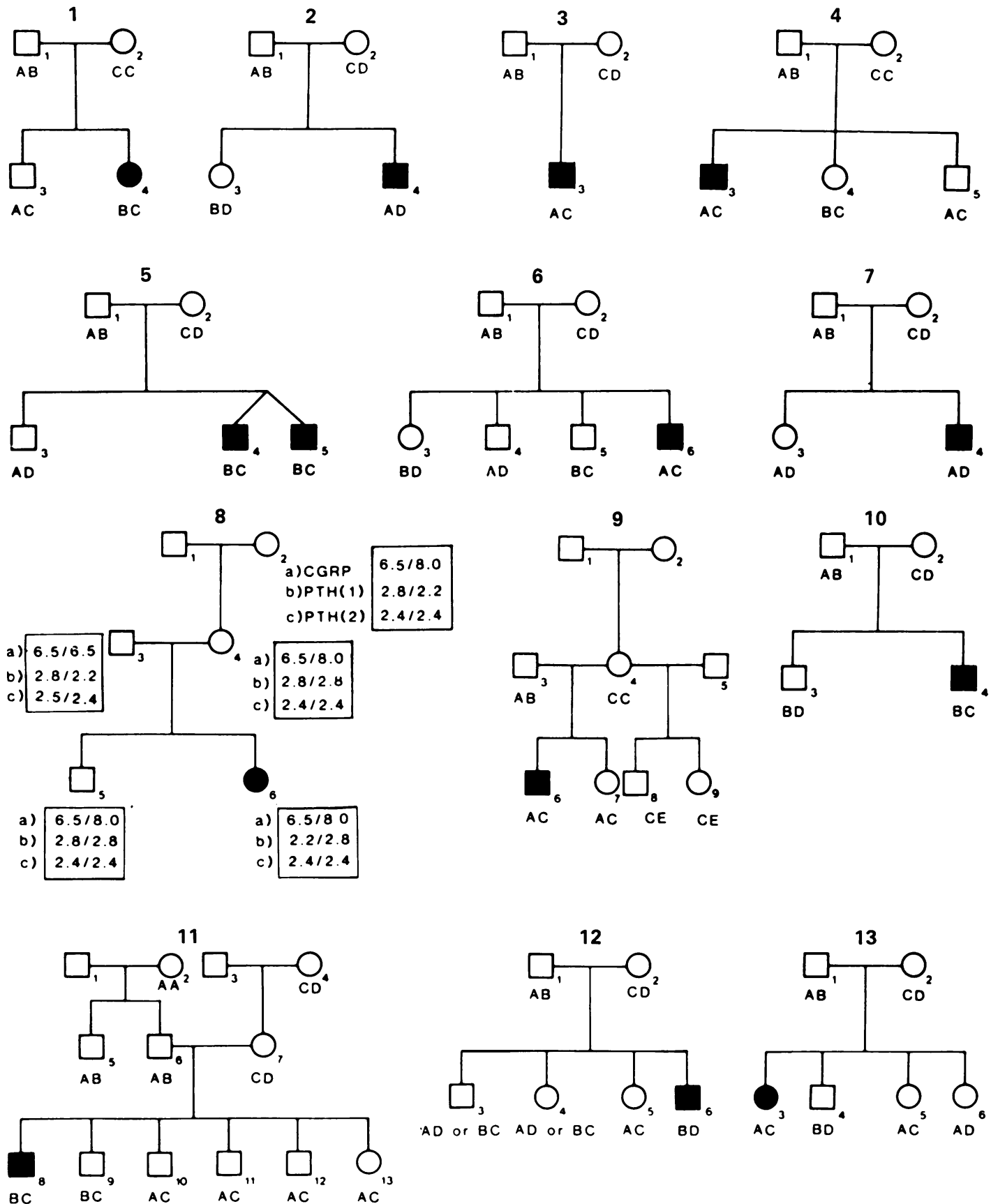

FIG 1 Pedigrees studied together with results of the calcitonin-CGRP parathormone gene haplotyping. Letters under symbols $=$ haplotypes which are detailed in table 2. Parental haplotypes $A B$ and $C D$ were derived by combinations of a calcitonin-CGRP TaqI RFLP, a TaqI parathormone gene RFLP, and a parathormone gene PstI RFLP. The parental haplotypes $A B$ and $C D$ are not the same for each family but are abbreviations, the key to which is given in table 2 . In family 8 there is recombination between the parathormone PstI and TaqI RFLPs and hence the full data are shown with the pedigree. 
TABLE 1 Gene mapping of the calcitonin CGRP gene complex in IHWBS.

\begin{tabular}{|c|c|c|c|c|c|c|c|}
\hline \multirow[t]{2}{*}{ Enzyme } & \multirow{2}{*}{$\begin{array}{l}\text { Fragment } \\
\text { size }\end{array}$} & \multicolumn{4}{|c|}{ Probe } & \multirow[b]{2}{*}{$E$} & \multirow[b]{2}{*}{$F$} \\
\hline & & $A$ & $B$ & c & D) & & \\
\hline \multirow[t]{4}{*}{ TaqI } & $2 \cdot 9$ & + & - & + & - & - & - \\
\hline & $2 \cdot 6$ & - & + & + & - & - & - \\
\hline & $8 \cdot 0 / 6 \cdot 5^{x}$ & - & - & - & + & + & + \\
\hline & $2 \cdot 5$ & - & - & - & - & + & + \\
\hline \multirow[t]{5}{*}{$B g I I I$} & $2 \cdot 1$ & + & - & NT & - & - & NT \\
\hline & $4 \cdot 1$ & + & + & NT & - & - & NT \\
\hline & 0.45 & - & - & NT & - & + & $\mathrm{NT}$ \\
\hline & 0.6 & - & - & $\mathrm{NT}$ & - & + & $\mathrm{NT}$ \\
\hline & $9 \cdot 4$ & - & - & $\mathrm{NT}$ & - & - & NT \\
\hline \multirow[t]{5}{*}{ PvuII } & $3 \cdot 4$ & + & + & NT & - & - & NT \\
\hline & $2 \cdot 4$ & + & + & NT & - & - & NT \\
\hline & $2 \cdot()$ & - & - & NT & + & + & NT \\
\hline & $3 \cdot 4$ & - & - & NT & - & + & $\mathrm{NT}$ \\
\hline & $5 \cdot 4$ & - & - & $\mathrm{NT}$ & - & + & $\mathrm{NT}$ \\
\hline \multirow[t]{6}{*}{ PstI } & $2 \cdot 3$ & + & - & - & - & - & $\mathrm{NT}$ \\
\hline & $2 \cdot 1$ & + & + & + & - & - & NT \\
\hline & 0.72 & - & - & + & - & - & $\mathrm{NT}$ \\
\hline & 1.9 & - & - & + & - & - & $\mathrm{NT}$ \\
\hline & $4 \cdot 0$ & - & - & - & - & - & $\mathrm{NT}$ \\
\hline & $5 \cdot 7$ & - & - & - & - & + & $\mathrm{NT}$ \\
\hline \multirow[t]{7}{*}{ SacI } & $3 \cdot 8 \div$ & + & - & NT & - & - & $\mathrm{NT}$ \\
\hline & $6 \cdot 8$ & + & + & NT & - & - & NT \\
\hline & $9.5 \div$ & - & + & NT & - & - & NT \\
\hline & $2 \cdot 6$ & - & + & NT & - & - & NT \\
\hline & 0.6 & - & - & NT & - & - & $\mathrm{NT}$ \\
\hline & $9 \cdot 3$ & - & - & NT & - & - & $\mathrm{NT}$ \\
\hline & $4 \cdot 2$ & - & - & $\mathrm{NT}$ & - & - & $\mathrm{NT}$ \\
\hline
\end{tabular}

Probes A to F are detailed in fig 2. Figures refer to size of gene fragments in kilobases determined by Southern blot techniques. No differences were observed in size of fragments between the IHWBS children and the rest of their families (pedigrees are detailed in tig 1 ).

*Polymorphic fragment with two alleles sized 8 and $6.5 \mathrm{kh}$

+ Hybridisation bands which cannot be explained by gene mapping but ar highly reproducible in all studies.

NT $=$ not tested.$+=$ present.$-=$ absent

reasons. Many authors have suggested an abnormality in calcium homeostasis. ${ }^{13-19}$ In 1972 Forbes et $a l^{17}$ suggested that the defect was of calcitonin production and this observation was followed up by Floyd et $a l^{20}$ who showed a failure of calcitonin release in response to a calcium challenge in children with IHWBS. Calcitonin gene related peptide (CGRP) is a neuropeptide widely distributed in the central nervous system and is also present in the vascular nerve supply where it acts as a powerful vasodilator. 21 Thus it is conceivable that a mutation in the calcitonin-CGRP complex might lead to hypercalcaemia. mental deficiency, and hypertension.

We therefore (1) investigated IHWBS families by restriction mapping of the calcitonin-CGRP gene of affected children and those of their family. seeking for a germ cell mutation; and (2) conducted family studies for segregation of calcitonin-CGRP and parathormone genes with the IHWBS gene. The parathormone gene is located on the short arm of chromosome 11 near the calcitonin-CGRP gene.

\section{Methods}

Thirteen families were identified by the Infantile Hypercalcaemia Foundation all of which had at least one member with IHWBS. All patients with IHWBS had had a documented episode of hypercalcaemia in infancy and met the strict criteria for diagnosis defined by Martin et al. ${ }^{+}$Family pedigrees are shown in fig 1 .

DNA was extracted from 10 to $20 \mathrm{ml}$ blood samples (anticoagulated with EDTA) from probands and all available family members, and separately digested with TaqI. BglII. PvulI. PstI, and SacI. ${ }^{22}$ The resulting DNA fragments were separated by size on a $1 \%$ agarose gel and transferred to Gene Screen Plus membranes using an alkaline Southern blot technique as previously described. ${ }^{23}$ The membranes were hybridised to $2 \mathrm{P}$ labelled gene probes. washed down to a stringency of $0.2 \mathrm{SSC}$, and gene sequences detected by autoradiography. Fragments were sized by comparison with HindIII digested lambda phage and an internal control.

GENE PROBES

Gene probes used in the study were all kindly donated by Professor R Craig (Courtauld Institute

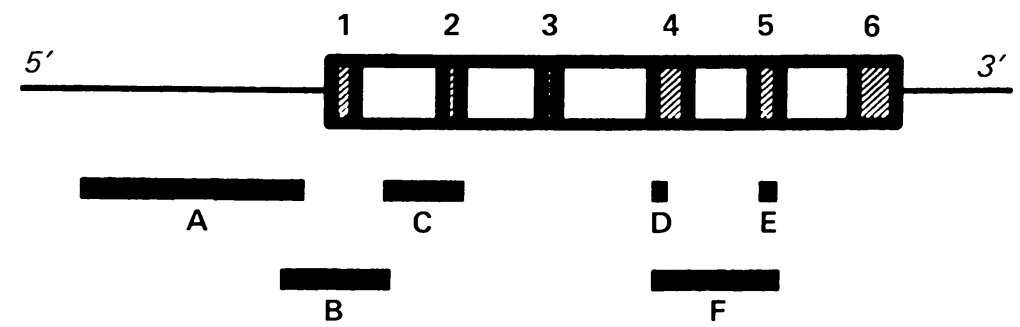

Gene probes used in study
FIG 2 The calcitonin/calcitonin gene related peptide (CGRP) complex and gene probes used.

\begin{tabular}{|c|c|c|c|}
\hline & Size & Plasmid code & $\begin{array}{l}\text { Inse't cutting } \\
\text { sites }\end{array}$ \\
\hline & $3.6 \mathrm{~kb}$ & $p(i E M C A L .22$ & EcoRI. Bo \\
\hline$B$ & $1.3 .3 \mathrm{kh}$ & $p(; E M C A L I 2$ & $P \mathrm{~s} t l$ \\
\hline C & $1 \cdot 1 \mathrm{~kb}$ & $p(B E M C A L I 2$ & Hpall \\
\hline$D$ & $0 \cdot 26 \mathrm{~kb}$ & $P h T-B 5$, & Sphl Sacl \\
\hline$E$ & $0 \cdot 3 \quad k b$ & $P h T-B 58$ & $\mathrm{Nicol}$ \\
\hline . & $1.64 \mathrm{~kb}$ & $P h T-B 58$ & $P \mathrm{~s} t I$ \\
\hline
\end{tabular}

Shaded revions refer to exoms troms l to and 7 are expressed in tisstues producing calcitonin and exoms 1 to 3 and 5 in those synthesising (CiRP. Exon o codes for a 3 untranslated region including the polv-A tail. 
TABLE 2 Calcitonin CGRP/parathormone gene haplotypes found in IHWBS pedigrees (see fig 1).

\begin{tabular}{|c|c|c|c|c|c|c|c|c|c|c|c|}
\hline$\frac{\text { Code }}{1 \mathrm{~A}}$ & \multicolumn{3}{|c|}{ Haplotype } & $\frac{\text { Code }}{2 \mathrm{~A}}$ & \multicolumn{3}{|c|}{ Haplotype } & $\frac{\text { Code }}{3 \mathrm{~A}}$ & \multicolumn{3}{|c|}{ Haplotype } \\
\hline $\begin{array}{l}1 \mathrm{~A} \\
1 \mathrm{~B} \\
1 \mathrm{C}\end{array}$ & $\begin{array}{l}6 \cdot 5 \\
8 \cdot 0 \\
8 \cdot 0\end{array}$ & $\begin{array}{l}2 \cdot 8 \\
2 \cdot 8 \\
2 \cdot 8\end{array}$ & $\begin{array}{l}2 \cdot 5 \\
2 \cdot 5 \\
2 \cdot 5\end{array}$ & $\begin{array}{l}2 \mathrm{~A} \\
2 \mathbf{B} \\
2 \mathrm{C} \\
2 \mathrm{D}\end{array}$ & $\begin{array}{l}6 \cdot 5 \\
6 \cdot 5 \\
6 \cdot 5 \\
8 \cdot 0\end{array}$ & $\begin{array}{l}2 \cdot 8 \\
2 \cdot 2 \\
2 \cdot 2 \\
2 \cdot 8\end{array}$ & $\begin{array}{l}2 \cdot 4 \\
2 \cdot 4 \\
2 \cdot 4 \\
2 \cdot 4\end{array}$ & $\begin{array}{l}3 \mathrm{~A} \\
3 \mathrm{~B} \\
3 \mathrm{C} \\
3 \mathrm{D}\end{array}$ & $\begin{array}{l}6 \cdot 5 \\
6 \cdot 5 \\
6 \cdot 5 \\
8 \cdot 0\end{array}$ & $\begin{array}{l}2 \cdot 8 \\
2 \cdot 2 \\
2 \cdot 2 \\
2 \cdot 8\end{array}$ & $\begin{array}{l}2 \cdot 5 \\
2 \cdot 4 \\
2 \cdot 4 \\
2 \cdot 4\end{array}$ \\
\hline $\begin{array}{l}4 A \\
4 B \\
4 C\end{array}$ & $\begin{array}{l}6 \cdot 5 \\
6 \cdot 5 \\
6 \cdot 5\end{array}$ & $\begin{array}{l}2 \cdot 8 \\
2 \cdot 2 \\
2 \cdot 8\end{array}$ & $\begin{array}{l}2 \cdot 5 \\
2 \cdot 4 \\
2 \cdot 5\end{array}$ & $\begin{array}{l}5 A \\
5 B \\
5 C \\
5 D\end{array}$ & $\begin{array}{l}6.5 \\
8 \cdot 0 \\
6 \cdot 5 \\
8 \cdot 0\end{array}$ & $\begin{array}{l}2 \cdot 2 \\
2 \cdot 2 \\
2 \cdot 8 \\
2 \cdot 2\end{array}$ & $\begin{array}{l}2 \cdot 4 \\
2 \cdot 4 \\
2 \cdot 5 \\
2 \cdot 4\end{array}$ & $\begin{array}{l}6 A \\
6 B \\
6 C \\
6 D\end{array}$ & $\begin{array}{l}6 \cdot 5 \\
8.0 \\
6 \cdot 5 \\
8.0\end{array}$ & $\begin{array}{l}2 \cdot 8 \\
2 \cdot 8 \\
2 \cdot 8 \\
2 \cdot 2\end{array}$ & $\begin{array}{l}2 \cdot 4 \\
2 \cdot 5 \\
2 \cdot 4 \\
2 \cdot 4\end{array}$ \\
\hline $\begin{array}{l}7 A \\
7 B \\
7 C \\
7 D\end{array}$ & $\begin{array}{l}6.5 \\
8.0 \\
6.5 \\
8.0\end{array}$ & $\begin{array}{l}2 \cdot 8 \\
2 \cdot 8 \\
2 \cdot 2 \\
2 \cdot 8\end{array}$ & $\begin{array}{l}2 \cdot 5 \\
2 \cdot 5 \\
2 \cdot 5 \\
2 \cdot 5\end{array}$ & $\begin{array}{l}9 \mathrm{~A} \\
9 \mathrm{~B} \\
9 \mathrm{C} \\
9 \mathrm{D}\end{array}$ & $\begin{array}{l}8.0 \\
8 \cdot 0 \\
6 \cdot 5 \\
6 \cdot 5\end{array}$ & $\begin{array}{l}2 \cdot 8 \\
2 \cdot 2 \\
2 \cdot 8 \\
2 \cdot 2\end{array}$ & $\begin{array}{l}2 \cdot 5 \\
2 \cdot 4 \\
2 \cdot 5 \\
2 \cdot 4\end{array}$ & $\begin{array}{l}10 A \\
10 B \\
10 C \\
10 D\end{array}$ & $\begin{array}{l}6.5 \\
8.0 \\
8.0 \\
8.0\end{array}$ & $\begin{array}{l}2 \cdot 2 \\
2 \cdot 8 \\
2 \cdot 8 \\
2 \cdot 2\end{array}$ & $\begin{array}{l}2 \cdot 4 \\
2 \cdot 4 \\
2 \cdot 5 \\
2 \cdot 4\end{array}$ \\
\hline $\begin{array}{l}11 \mathrm{~A} \\
11 \mathrm{~B} \\
11 \mathrm{C} \\
11 \mathrm{D}\end{array}$ & $\begin{array}{l}6.5 \\
8.0 \\
6.5 \\
8.0\end{array}$ & $\begin{array}{l}2 \cdot 8 \\
2 \cdot 2 \\
2 \cdot 8 \\
2 \cdot 8\end{array}$ & $\begin{array}{l}2 \cdot 5 \\
2 \cdot 4 \\
2 \cdot 4 \\
2 \cdot 5\end{array}$ & $\begin{array}{l}12 \mathrm{~A} \\
12 \mathrm{~B} \\
12 \mathrm{C} \\
12 \mathrm{D}\end{array}$ & $\begin{array}{l}6 \cdot 5 \\
6 \cdot 5 \\
8 \cdot 0 \\
8 \cdot 0\end{array}$ & $\begin{array}{l}2 \cdot 8 \\
2 \cdot 2 \\
2 \cdot 8 \\
2 \cdot 2\end{array}$ & $\begin{array}{l}2 \cdot 5 \\
2 \cdot 4 \\
2 \cdot 5 \\
2 \cdot 4\end{array}$ & $\begin{array}{l}13 \mathrm{~A} \\
13 \mathrm{~B} \\
13 \mathrm{C} \\
13 \mathrm{D}\end{array}$ & $\begin{array}{l}6.5 \\
8 \cdot 0 \\
6.5 \\
8.0\end{array}$ & $\begin{array}{l}2 \cdot 8 \\
2 \cdot 8 \\
2 \cdot 8 \\
2 \cdot 2\end{array}$ & $\begin{array}{l}2 \cdot 5 \\
2 \cdot 5 \\
2 \cdot 4 \\
2 \cdot 4\end{array}$ \\
\hline
\end{tabular}

Code. Number refers to pedigree number as in fig 1. A, B, C. and D are the haplotypes. Haplotype. Figures refer to the size of the restriction fragment length polymorphism for calcitonin-CGRP TaqI (sized $6 \cdot 5 / 8 \cdot 0 \mathrm{~kb}$ ), parathormone gene TaqI $(2 \cdot 8 / 2 \cdot 2 \mathrm{~kb})$, and parathormone gene PstI $(2 \cdot 5 / 2 \cdot 4 \mathrm{~kb})$ respectively.

of Biochemistry, Middlesex Hospital Medical School, London) and those used in the gene mapping study are detailed in table 1 and fig 2 . For the construction of calcitonin-CGRP/parathormone gene haplotypes a PstI insert of PhT-B58 (probe F, fig 2) and cDNA parathormone gene probe ${ }^{24}$ were used.

\section{Results}

Results from the mapping studies are presented in table 1. Restriction sites using the six probes and five enzymes encompassed approximately $13.5 \mathrm{~kb}$ in and around the calcitonin-CGRP gene. No differences were observed between the IHWBS children and their families in the size of DNA fragments for this region.

Calcitonin-CGRP/parathyroid gene haplotypes are shown in the families in fig 1 and table 2 . The TaqI calcitonin-CGRP polymorphism consisted of two allelic fragments sized 6.5 or $8.0 \mathrm{~kb}$, the parathormone TaqI polymorphism was sized 2.5 and $2.4 \mathrm{~kb},{ }^{25}$ and the parathormone PstI polymorphism was sized $2 \cdot 8$ and $2 \cdot 2 \mathrm{~kb} .{ }^{25}$

In three informative families the affected sib was identical to a normal sib for the calcitonin-CGRP/ parathormone locus (for example, in family 7 sibs 3 and 4 were both $A D$, in family 11 sibs 8 and 9 were $\mathrm{BC}$, and in family 13 sibs 3 and 5 were $\mathrm{AC}$ ). These families therefore provide direct evidence against IHWBS being a recessive disorder at this locus.

\section{Discussion}

Restriction mapping studies exclude a germ cell mutation leading to deletions or insertions of over
50 nucleotides affecting the calcitonin-CGRP gene. Restriction mapping would not detect point mutation $\mathscr{\odot}$ unless the mutation occurred within the enzymes recognition site. Since the enzymes used recognise $\square$ four to six base pair sequences and 27 sites were analysed, this analysis cannot exclude a point muta- $\frac{\bar{O}}{0}$ tion in the vast majority of sequences within this gene. An alternative to a germ cell mutation would $\mathbb{D}$ be gene damage during early embryogenesis, in $\underset{\Rightarrow}{\Rightarrow}$ which case analysis of leucocyte DNA would not necessarily show any abnormalities. Using probes $\mathrm{E} \frac{\mathrm{J}}{\sqrt{2}}$ and $\mathrm{F}$ a constant band for each enzyme, sized $2.5 \mathrm{~kb}$ (TaqI), $5.7 \mathrm{~kb}$ (PstI), and $4.2 \mathrm{~kb}$ (SacI) was identified which corresponds to a second CGRP gene. ${ }^{26}$ The latter has high homology with CGRP and is encoded by a gene separate from the 3 . calcitonin-CGRP gene complex. No differences in size of this second CGRP gene was found between the IHWBS children and their sibs.

Family studies provide evidence against this being an autosomal recessive condition with a defect at $\frac{D}{O}$ the calcitonin-CGRP gene complex. Recently, an analysis of the calcitonin-CGRP gene was carried $N$ out in a family with autosomal dominant supra- $N$ valvular aortic stenosis ${ }^{27}$ and the authors concluded ${ }_{N}$ that this gene was not linked to 'Williams' syndrome'. However, family members with SVAS were of normal intelligence and had normal facies, ${ }^{28}$ and $\stackrel{\circ}{ᄃ}$ therefore their study only rules out linkage of this $\stackrel{\Phi}{\Phi}$ locus with familial SVAS and not IHWBS.

Subjects with certain defined chromosomal abnormalities on the long arm of chromosome $15, \stackrel{\overrightarrow{\mathbb{D}}}{\mathrm{d}}$ the long arm of chromosome 4 , and a translocation $\frac{\rho}{\Phi}$ of the long arm of chromosomes 9 and 17 have been 2 described as having some features in common with? 
IHWBS. ${ }^{4} 2930$ This might be another starting point to examine loci associated with this syndrome.

Finally, perhaps the collagen genes should be studied given the wide range of connective tissue disorders in this syndrome, together with large vessel disorders similar to those of Marfan's syndrome, ${ }^{1}$ although this would not explain the hypercalcaemia or mental retardation. Future studies on the calcitonin-CGRP gene perhaps should include sequencing this gene in DNA obtained from tissues which produce CGRP or calcitonin or both, or long range gene mapping (by pulsed field gel electrophoresis) to search for deletions which might affect gene activity.

This work was supported by grants from the Infantile Hypercalcaemia Foundation and Action Research. We are grateful to Sir George and Lady Cooper for help in identifying and contacting the families, to the families and children for their cooperation, and to Professor R Craig, Middlesex Hospital, for helpful discussions and the provision of gene probes. Genetic advice was kindly given by Dr R M Winter, Kennedy Galton Centre, Clinical Research Centre, Harrow.

\section{References}

1 Williams JCP, Barratt-Boyes BG, Lowe JB. Supravalvular aortic stenosis. Circulation 1961:24:1311-8.

2 Beuren AJ, Schulze C. Eberle P, Harmjanz D, Apitz J. The syndrome of supravalvular aortic stenosis, peripheral pulmonary stenosis, mental retardation and similar facial appearance. $\mathrm{Am} \mathrm{J}$ Cardiol 1964:13:471-83.

3 Black JA. Bonham Carter RE. Association between aortic stenosis and facies of severe infantile hypercalcaemia. Lancet 1963;ii:745-8.

4 Martin NDT. Snodgrass GJAI. Cohen RD. Idiopathic infantile hypercalcaemia-a continuing enigma. Arch Dis Child 1984;59: 605-13.

5 Pagon RA, Bennett FC, LaVeck B. Stewart KB, Johnson J. Williams syndrome: features in late childhood and adolescence. Pediatrics 1987:80:85-91.

${ }^{6}$ Burn J. Williams syndrome. J Med Genet 1986:23:389-95.

7 Wiltse HE, Goldbloom RB. Antia AY. Ottesen OE. Rowe RD. Cooke RE. Infantile hypercalcaemia syndrome in twins. $N$ Engl J Med 1966:275:1157-60.

${ }^{8}$ White RA, Preus M, Watters GV, Fraser FC. Familial occurrence of Williams syndrome. Clin Genet 1980;18:173-6.

9 Cortada X. Tays K. Hartmann AF. Familial Williams syndrome. Clin Genet 1980:18:173-6.

10 Westgren M. Eastham WN. Ghandourah S. Woodhouse N. Intrauterine hypercalcaemia and non-immune hydrops fetalisrelationship to the Williams syndrome. Prenat Diagn 1988;8: 333-7.

"Craig RK. Hall L. Edbrooke MR. Allison J. Macintyre I. Partial nucleotide sequence of human calcitonin precursor mRNA identifies flanking cryptic peptides. Nature 1982:295: 345-7.
12 Hoppener JWM, Steenberga PH, Zandberg J, et al. Localisation of the polymorphic human calcitonin gene on chromosome 11 . Hum Genet 1984;66:309-12.

13 Friedman WF, Roberts WC. Vitamin D and the supravalvular aortic stenosis system. The transplacental effects of vitamin D on the aorta of the rabbit. Circulation 1966;34:77-86.

14 Friedman WF, Mills LF. The relationship between vitamin D and the craniofacial and dental anomalies of the supravalvular aortic stenosis syndrome. Pediatrics 1969:43:12-18.

15 Becroft DMO, Chambers D. Supravalvular aortic stenosisinfantile hypercalcaemia syndrome: in vitro hypersensitivity to vitamin D2 and calcium. J Med Genet 1976;12:223-8.

16 Barr DGD, Forfar JO. Oral calcium-loading test in infancy with particular reference to idiopathic hypercalcaemia. $\mathrm{Br}$ Med $\mathrm{J}$ 1969;i:477-80.

${ }^{17}$ Forbes GB, Bryson MF, Manning J, et al. Impaired calcium homeostasis in the infantile hypercalcaemic syndrome. Acta Paediatr Scand 1972:61:305-9.

18 Daiger SP, Miller M, Romeo G, Paisons M, Cavalli-Sforza LL. Vitamin-D-binding protein in the Williams syndrome. $N$ Engl $J$ Med 1978;298:687-8.

19 Taylor AB, Stern PH, Bell NH. Abnormal regulation of circulating 25 -hydroxyvitamin $\mathrm{D}$ in the Williams syndrome. $N$ Engl J Med 1982;306:972-5.

20) Floyd L, Jones KL, Deftos LJ. Impaired calcitonin secretion in patients with Williams syndrome. J Pediatr 1985;5:720-3.

21 Brain SD, Williams TJ, Tippins JR, Morris HR, MacIntyre I. Calcitonin gene-related peptide is a potent vasodilator. Nature 1985:313:54-6.

22 Kunkel LM, Smith KD, Boyer SH, et al. Analysis of human $\mathrm{Y}$ chromosome specific reiterated DNA in chromosome variants. Proc Natl Acad Sci USA 1977:74:1245-9.

23 Hitman GA, Niven MJ, Festenstein $\mathrm{H}$, et al. HLA class II alpha chain gene polymorphisms in patients with insulin-dependent diabetes mellitus, dermatitis herpetiformis and celiac disease. J Clin Invest 1987:79:609-15.

${ }^{24}$ Hendy GN. Kronenberg HM, Potts JT Jr. Rich A. Nucleotide sequence of cloned cDNAs encoding human preproparathyroid hormone. Proc Natl Acad Sci USA 1981;78:7365-9.

25 Schmidtke J, Pape B, Krengel U, et al. Restriction fragment length polymorphisms at the human parathyroid hormone gene locus. Hum Genet 1984:67:428-31.

26 Steenbergh PH. Hoppener JNM, Zandberg J, Lips CJM. Jansc HS. A second human calcitonin/CGRP gene. FEBS Lett 1985:183:403-7.

${ }^{27}$ Bennett CP, Burn J, Moore GE, Chambers J, Williamson R. Wilkinson J. Exclusion of calcitonin as a candidate gene for the basis defect in a family with autosomal dominant supravalvular aortic stenosis. J Med Genet 1988;25:311-2.

28 Logan WFWE. Wyn Jones E. Walker E. Coulshed N. Epstein EJ. Familial supravalvular aortic stenosis. Br Heart $J$ 1965;27: 547-59.

29 Kaplan LC. Wharton R. Elias E. Mandell F, Donion T, Latt SA. Clinical heterogencity associated with deletions in the long arm of chromosome 15: report of three new cases and their possible genetic significance. Am J Med Genet 1987:28:45-53.

3) Jefferson RD. Burn J. Gaunt K L. Hunter S. Davison EV. A terminal deletion of the long arm of chromosome 4 (46.XX. $\operatorname{del}(4)(\mathrm{q} 33))$ in an infant with phenotypic features of Williams syndrome. J Med Genet 1986:23:474-80.

Correspondence to Dr G A Hitman, Medical Unit, The London Hospital Medical College, Whitechapel, London E1 1BB. 